\title{
Isu Pemanasan Global dalam Pergeseran Paradigma Keamanan pada Studi Hubungan Internasional
}

\author{
Adibah Sayyidati \\ Badan Penelitian dan Pengembangan Provinsi Jawa Timur \\ Gayungan, Kota Surabaya, Jawa Timur 60235 \\ adibah_sayyidati@yahoo.com \\ Diserahkkan: 19 Desember 2016, Diterima: 6 Februari 2017
}

\begin{abstract}
For many years, International Relations (IRs) has focused its discussion on politico-military theme, where the states were the main actor in this study. This tradition is known as realism. As time went by, the golden age of realism paradigm comes to an end because it couldn't cope with the complicated problem faced by international community. That is why IRs begins to broaden and deepen its object of discussion to nonmilitary topics, such as economics, politics, social, and environment. In a brief, IRs discourse moves from state security to human security. As what has been explained, economics is one of many sectors that get attention the most because this theme related to human activity on fulfilling their daily basic needs. But, this activity causes undesired effect to the environment, such as global warming, that should be handled as soon as possible. It encourages international community to begin paying attention to this issue at last decade. Global warming as the one of the biggest issue in environmental security is the trigger of it. This topic also made environmental issue to be IRs focus of study as well as another aspect, such as military, economics, and politics.

Keywords: International Relations study, human security, environmental issue, global warming.
\end{abstract}

\begin{abstract}
Abstrak
Artikel ini memaparkan perubahan jangkauan pembahasan studi Hubungan Internasional (HI) dari tema-tema politik dan militer di mana negara menjadi aktor utama dalam disiplin ilmu ini yang kemudian berkembang menjadi tema-tema seperti ekonomi, sosial, dan lingkungan sehingga tidak lagi hanya fokus pada topik-topik politik dan militer. Dengan kata lain, disiplin ilmu HI telah menggeser fokus obyek kajiannya dari keamanan negara menjadi keamanan manusia yang meliputi tema-tema non-militer. Ekonomi menjadi salah satu bidang yang mendapat perhatian lebih karena aspek ini terkait dengan aktifitas manusia untuk memenuhi kebutuhan hidupnya. Namun aktifitas ekonomi ini juga membawa efek samping, seperti pemanasan global, yang harus ditangani seefektif mungkin. Inilah yang melatarbelakangi besarnya perhatian komunitas internasional pada fenomena tersebut dalam beberapa dekade terakhir. Pemanasan global ini juga mengantarkan tema lingkungan untuk menyejajarkan dirinya dengan aspek-aspek lain seperti ekonomi dan politik sebagai fokus kajian HI.

Kata kunci: Ilmu Hubungan Internasional, keamanan manusia, lingkungan, pemanasan global.
\end{abstract}

\section{PENDAHULUAN}

Ilmu Hubungan Internasional (HI) muncul sebagai bidang studi yang terorganisasi pada awal abad 20. Menurut Edward H. Carr (1939), munculnya HI sebagai bidang studi tersendiri-setelah sebelumnya menjadi bagian dari ilmu sejarah-adalah akibat adanya keinginan, terutama sesudah Perang Dunia I, untuk memahami sebab-sebab terjadinya konflik yang pada akhirnya ditujukan guna mencari langkah-langkah preventif agar tidak terjadi pertikaian

antar-negara serta tercipta dunia yang lebih damai. Kebutuhan yang bersifat normatif itu menjadikan diplomasi serta hukum dan organisasi internasional sebagai isi pokok studi baru ini. Ini mencerminkan optimisme umum abad 19, yakni perdamaian bisa diciptakan melalui pembuatan aturan main.

Namun, apa yang dipercaya oleh paradigma normatif ini runtuh setelah timbul realitas politik praktis pada tahun 
1930-an. Saat itu, muncul diktator-diktator ekspansionis yang dengan sengaja mengabaikan tertib hukum dan lembaga internasional. Ekspansi Jerman ke Polandia yang berujung pada munculnya Perang Dunia II adalah contohnya. Usainya Perang Dunia II tidak serta-merta membuat dunia berselimut kedamaian. Masyarakat internasional pun masuk dalam babak baru konflik di tingkat global yang terkenal dengan sebutan Perang Dingin.

Kegagalan paradigma normatif dalam menjelaskan alasan negara melakukan ekspansi yang berujung pada perang telah memunculkan pendekatan baru. Pendekatan baru ini disebut paradigma realisme. Paradigma tersebut berasumsi bahwa politik internasional merupakan sarana perebutan kekuasaan antarnegara. Oleh karenanya, perang terjadi di mana-mana karena masing-masing negara berusaha mencapai kepentingan nasionalnya, yaitu memperoleh kekuasaan agar bisa bertahan dalam sistem internasional. Sistem internasional yang anarkis ini menuntut negara-negara untuk membangun kekuatan militer yang mampu mencegah serangan lawan. Bagi sebuah negara, kemampuan militer lebih penting daripada kapabilitas ekonomi untuk membangun wibawa dan kekuatan nasionalnya.

Paradigma realisme ini mendominasi teoritisi HI selama kurang lebih 2 dasawarsa sesudah Perang Dunia II. Realisme mungkin menjadi paradigma yang paling berpengaruh karena tiga alasan. Pertama, ia menjadi perspektif sentral dalam dunia akademik. Kedua, paradigma ini dominan dalam jurnalisme. Terakhir, realisme menjadi pondasi bagi pembuatan kebijakan luar negeri.

Seperti halnya paradigma sebelumnya, realisme pun menuai tidak sedikit kritik dan mulai digeser oleh pendekatan yang lain. Pergeseran konsep dan kebijakan yang dipakai dalam $\mathrm{HI}$ ini menemui momentumnya pada akhir Perang Dingin (Thomas dan Tow, 2002: 177). Pada saat itu, studi HI lebih diwarnai oleh agenda-agenda dalam bidang lain, seperti ekonomi, lingkungan, dan sosial. Kemunculan isu-isu ini didorong oleh ketidakpuasan akan semakin intensif dan menyempitnya studi HI pada bidang keamanan, khususnya mengenai pengembangan kekuatan militer dan nuklir pada saat Perang Dingin. Agenda-agenda ekonomi dan lingkungan mulai mengemuka dalam kajian HI pada dekade 1970-an dan 1980-an. Pada dekade berikutnya, HI mulai diwarnai dengan isu-isu dalam hal identitas dan kejahatan kriminal transnasional (Buzan, et. al., 1998: 2).

Perluasan kajian dalam studi HI ini mengubah perspektif masyarakat dunia dalam mendefinisikan keamanan. Redefinisi ini merupakan tanggapan atas konsep keamanan yang lebih memfokuskan perhatiannya pada negara yang tak lagi dapat menjawab persoalan hidup manusia. Negara yang aman secara wilayah dari agresi negara lain belum tentu menjamin keberlangsungan hidup rakyatnya. Oleh karena itu, perubahan paradigma dalam studi HI mengarah ke keamanan manusia untuk menjawab luasnya dimensi persoalan di dalamnya.

Keamanan manusia yang semakin mendapat perhatian dalam studi HI mencakup bidang yang lebih luas yang meliputi ekonomi, politik, sosial, lingkungan, dan sebagainya. Isu lingkungan kemudian mendapat porsi perhatian yang lebih dari masyarakat internasional setelah mencuatnya pemanasan global. Isu yang dipandang sebagai ancaman keberlangsungan hidup manusia ini telah mengundang aktor-aktor dalam HI untuk menyusun agenda sekuritisasi.

\section{PEMBAHASAN}

\section{PERGESERAN STUDI HUBUNGAN INTERNASIONAL}

Setelah Perang Dingin berakhir, isu-isu sosial, ekonomi, dan lingkungan seakan semakin leluasa mewarnai diskursus hubungan internasional sebab hal ini mengesankan bahwa ancaman terhadap kedaulatan suatu negara menurun. Konsekuensinya adalah tugas utama studi strategi-menganalisis konfrontasi Barat-Timur saat Perang Dingin-yang menjadi inti konsep keamanan dalam pendekatan realisme pun lambat-laun berkurang. Oleh karena itu, fokus militer dalam analisis strategis menjadi sangat rapuh terhadap berkembangnya isu-isu non-militer dalam diskursus HI (Buzan, et.al., 1998:3). Penurunan ancaman terhadap kedaulatan negara ini diikuti dengan peningkatan ancaman terhadap eksistensi manusia, seperti kemiskinan, penyakit menular, bencana alam, kerusakan lingkungan hidup, terorisme, dan sebagainya.

Namun, negara sepertinya tidak lagi mampu berhadapan dengan permasalahan-permasalahan di atas dengan baik. Negara seolah kehilangan otoritas atas apa yang 
seharusnya ia tangani. Konsekuensinya adalah apa yang seharusnya menjadi tanggung jawab negara kini telah berpindah ke tangan aktor-aktor non-negara. Bahkan, kehidupan sehari-hari masyarakat pun seakan semakin kebal dari aktivitas dan kebijakan pemerintah (Held dan McGrew, 2003: 127-128). Inisiatif-inisiatif dari kalangan akar rumput pun bermunculan untuk mengatasi masalah kesehariannya sendiri ketika mereka merasa tidak bisa lagi menyandarkan bebannya pada negara. Menurunnya otoritas pemerintah ini merupakan akibat dari perubahan pada bidang teknologi serta integrasi yang semakin cepat dalam sebuah ekonomi pasar global (Held dan McGrew, 2003:133). Dalam hal ini, kemunculan aktor-aktor nonnegara dalam sistem internasional telah memperluas obyek studi HI.

Isu-isu ekonomi politik internasional bisa dijadikan contoh untuk menunjukkan fenomena ini. Institusi ekonomi internasional beserta perusahaan multinasional menjadi pihak yang lebih berperan dalam menentukan bagaimana kebijakan sebuah negara. Bahkan, kompetisi dalam pasar dunia telah berhasil mengalihkan perhatian masyarakat internasional dari permasalahan seputar perebutan wilayah ataupun kontrol atas sumber daya alam di suatu wilayah. Negara-negara saling berlomba untuk mencari sekutu dalam bidang ekonomi, tidak lagi dalam masalah keamanan untuk memperkuat kemampuan militernya (Held dan McGrew, 2003:131).

Fakta-fakta inilah yang memunculkan premis bahwa studi HI telah bergeser dari yang sebelumnya lebih fokus pada bidang politik-militer menuju isu-isu non-militer. Pun demikian halnya dengan aktor-aktor yang bermain di dalamnya. Studi HI yang semula hanya terpusat pada negara, kini mulai menaruh perhatian pada aktor-aktor non-negara yang juga berandil besar dalam interaksi global.

\section{MUNCULNYA GAGASAN KEAMANAN MANUSIA}

Gagasan keamanan mengalami perkembangan sejalan dengan fenomena yang terjadi dalam Hubungan Internasional. Politik militer tradisional melihat negara sebagai obyek keamanan dalam konteks kelangsungan hidup. Suatu isu dapat menjadi ancaman ketika mengancam kedaulatan atau wilayah suatu negara. Ini menjadi legitimasi penggunaan angkatan bersenjata atau kekuatan lain untuk mengatasi ancaman yang ada.

Alternatif penjelasan politik keamanan mulai mengemuka di dekade 1990-an. Saat itu, politik keamanan mulai meluaskan perhatiannya pada isu-isu lain, seperti akses makanan pokok, kualitas lingkungan global, serta kesejahteraan ekonomi masyarakat di negara berkembang. Objek keamanan tak lagi hanya negara, tetapi meluas pada individu yang mendiami wilayah itu.

Seperti halnya pergeseran obyek studi HI-dari yang semula didominasi oleh pendekatan realis dengan kapasitas militer negara sebagai intinya ke bidang-bidang non-militeryang berlatar belakang adanya kekecewaan, maka kemunculan ide keamanan manusia juga tak terlepas dari latar belakang yang sama. Adanya kekecewaan pada konsep pembangunan dan keamanan yang berlaku pada dekade 1960-an hingga 1980-an lah yang membuat konsep keamanan manusia mengemuka (Bajpai, 2003:195). Berbagai kritik terhadap pembangunan ekonomi mulai dilancarkan pada dekade 1960-an karena kegagalannya mengatasi ancaman kelangsungan hidup manusia. Di samping itu, akhir konfrontasi bipolar antara blok Barat dan Timur yang memunculkan argumen tentang perdamaian yang demokratis juga berkontribusi pada desakan untuk meredefinisi studi keamanan. Topik-topik keamanan klasik, seperti kontrol senjata, perang, dan nuklir seolah kehilangan urgensinya karena dianggap tidak bersentuhan langsung dengan kehidupan sehari-hari masyarakat yang bergelut dengan masalah-masalah kompleks, misalnya di bidang ekonomi, sosial, dan lingkungan. Gagasan-gagasan untuk mengatasi ancaman mulai diluncurkan oleh berbagai pihak, seperti pusat studi keamanan, komisi independen, dan kelompok lain. Kelompok-kelompok ini mencoba menjelaskan kompleksitas sistem internasional yang mempengaruhi kehidupan manusia serta menyediakan jalan alternatif mengonsep pembangunan global yang memungkinkan dan dapat meningkatkan kesempatan hidup.

Dalam hal ini, salah satu laporan yang berorientasi pada keamanan manusia dikeluarkan oleh United Nations Development Programme (UNDP). Laporan tersebut adalah UNDP's Human Development Report 1994 yang berjudul Dimensions of Human Security. Dalam laporan itu, 
terdapat tujuh kategori ancaman yang terkait dengan keamanan manusia. Ketujuhnya adalah ancaman ekonomi, makanan, kesehatan, lingkungan, personal, komunitas, dan politik. Negara yang aman, dalam konteks batas wilayah, masih dapat mengancam keamanan manusia yang mendiaminya. Laporan tersebut mengimplikasikan fokus keamanan internasional harus diperluas sehingga tak hanya menaruh perhatian pada aspek batas wilayah, tetapi juga kehidupan penduduk.

Seperti dijelaskan di atas, bidang ekonomi merupakan bagian dari keamanan bagi kehidupan penduduk. Dalam hal ini, keamanan ekonomi bisa dilihat dari sisi pemenuhan kebutuhan dasar rakyat suatu negara. Untuk memenuhi fungsi ini, maka penduduk suatu negara pun melakukan berbagai aktivitas ekonomi. Namun, kegiatan ini seringkali membawa dampak buruk bagi lingkungan mereka.

\section{Human Insecurity: Aktivitas Ekonomi Manusia dan Degradasi Lingkungan}

Aktivitas ekonomi manusia bertambah sejalan dengan naiknya populasi. Kebutuhan yang seakan tak pernah cukup mendorong manusia untuk terus mengeksploitasi bumi dan meningkatkan aktivitas produksi. Ekonomi liberal yang membuka saluran perdagangan lintas batas negara turut melanggengkan aktivitas produksi industri yang berlebihan. Begitu juga dengan pola konsumsinya. Perdagangan bebas dilakukan untuk mencari keuntungan maksimal dengan mendorong masyarakat untuk menjadi konsumtif. Aktifitas produksi juga cenderung dijalankan tanpa mempertimbangkan dampak sosial dan lingkungan. Ekonomi liberal gagal dalam menanggapi kenyataan bahwa pertumbuhan produksi dan konsumsi juga meningkatkan dampak buruk bagi lingkungan (Worku, 2007).

Permasalahan itu jugalah yang dibahas dalam 'Rio Plus Five' United Nations (UN) Earth Summit 1997 (Kegley dan Wittkopf, 2001:398). Sementara itu, tingkat pertumbuhan populasi semakin bertambah dan tidak diimbangi dengan jumlah sumber daya alam yang ada. Padahal, level konsumsi terus naik. Dalam hal ini, 20\% penduduk dunia mengonsumsi $80 \%$ sumber daya alam. Bahkan, beberapa negara berkembang yang memiliki populasi besar bergerak ke gaya hidup konsumtif.
Inilah yang dipandang sebagai paradoks dalam isu keamanan lingkungan (de Wilde, 2008). Kenyataan bahwa gaya hidup kontemporer yang ditopang oleh struktur global saat ini memang tidak bisa dipungkiri telah menyebabkan permasalahan lingkungan. Hal itulah yang memunculkan dilema di antara dua pilihan, yakni memberikan kesempatan pada struktur global yang selama ini eksis untuk berubah secara perlahan ataukah menanti hingga perubahan tersebut terjadi dengan cara tiba-tiba karena adanya krisis lingkungan (Trombetta, 2008:595).

Dampak yang diterima lingkungan akibat aktivitas manusia ini tak kalah memprihatinkan. Luas hutan mengecil. 33,8 juta acre hutan ditebang atau dibakar setiap tahunnya. Diperkirakan pada 2025, dua pertiga populasi dunia akan kesulitan mendapat air bersih. Pencemaran laut dan udara semakin tinggi akibat industri. Limbah pabrik mengandung logam berat berbahaya bagi manusia yang mengonsumsi hasil laut. Peningkatan racun dari limbah diperkirakan mencapai 3 juta ton. Limbah ini menyebar lintas batas negara tiap tahun. Di udara, gas emisi seperti karbondioksida, akan meningkatkan efek rumah kaca. Salah satu akibatnya adalah menghilangnya 50.000 jenis tanaman dan spesies hewan tiap tahun.

Tragedi kemanusian akibat limbah pernah tercatat dalam sejarah. Tragedi minamata menewaskan sekitar 3000 orang akibat pencemaran merkuri di Jepang. Pencemaran di Teluk Buyat yang mengganggu kesehatan penduduk di Sulawesi Utara akibat kegiatan industri, pernah menjadi catatan buruk di negeri ini. Limbah PT Newmont menghasilkan 4 juta ton tailing di dasar teluk. Akibatnya lebih dari $80 \%$ warga mengalami gangguan kesehatan serius dan bahkan meninggal akibat tercemar limbah. Masyarakat kehilangan pekerjaan sebagai nelayan akibat limbah dan terpaksa meninggalkan kampung halamannya.

\section{Lingkungan Sebagai Salah Satu Isu dalam Konsep Keamanan Manusia}

Dampak buruk yang terjadi pada lingkungan sebagai akibat aktivitas ekonomi manusia itu menjadi salah satu tantangan bagi studi HI. Tantangan tersebutlah yang berusaha dijawab oleh bidang ilmu ini dengan mulai menggeser obyek studinya, dari militer tradisional yang menekankan fokus kajiannya pada negara ke keamanan 
manusia. Pergeseran isu keamanan ini turut memperluas bidang cakupan isu yang menjadi perhatian dalam studi HI. Salah satu isu yang berkembang sejalan dengan kompleksitas aktifitas ekonomi masyarakat adalah permasalahan seputar lingkungan. Karenanya manusia mencoba mempertahankan lingkungan agar dapat menjaga kelangsungan hidup mereka saat ini maupun di masa depan.

Isu mengenai lingkungan muncul dalam pembicaraan di Konferensi Perserikatan Bangsa-Bangsa (PBB) pada 1972 (Buzan, et.al., 1998:71). Adanya kemungkinan untuk melihat isu lingkungan dalam konteks studi keamanan sebenarnya muncul sejak 1980-an namun kurang mendapat perhatian hingga awal 1990-an (Martinovsky, 2011:2). Isu lingkungan muncul di level global karena karakter lintas batas negara yang umumnya melekat pada permasalahan tersebut. Dalam hal ini, degradasi lingkungan merupakan masalah yang dihadapi oleh semua pemerintah dalam memenuhi kebutuhan rakyatnya. Selain itu, penurunan kualitas lingkungan juga akan mengurangi kesejahteraan ekonomi semua negara. Oleh karenanya diperlukan kerja sama antara pemerintah serta organisasi-organisasi internasional (Kegley dan Wittkopf, 2001:366). Pada dekade 1990-an, isu lingkungan pun menemukan momentumnya sebagai lensa dalam memandang politik.

Meski demikian, perluasan obyek studi ini bukan berarti tanpa hambatan. Masuknya topik lingkungan dalam diskursus keamanan seringkali dikaburkan oleh isu-isu lain yang dianggap lebih mendesak (Trombetta, 2008:585). Dalam hal ini, terorisme merupakan salah satu isu yang pada awal abad 21 dianggap lebih penting untuk segera ditangani daripada degradasi lingkungan (Trombetta, 2008:594). Tantangan lain juga datang dari beberapa penulis yang beranggapan bahwa konsep lingkungan dan keamanan tidak mungkin dihubungkan. Keamanan biasanya diasosiasikan dengan kekerasan. Ini mempengaruhi jenis institusi yang bertanggung jawab terhadap permasalahan lingkungan ataupun keamanan. Lembaga yang bertugas memberikan jaminan terhadap ancaman degradasi lingkungan tentu sama sekali berbeda dengan institusi yang bertanggung jawab untuk menyediakan perlindungan dalam melawan kekerasan. Kalaupun ada institusi keamanan, bahkan intelijen, dari pemerintah yang memberikan bantuan untuk menghadapi problem-problem seputar lingkungan, hal itu dipandang lebih sebagai upaya mereka untuk menjamin jumlah dana yang telah dianggarkan bagi lembaganya agar tetap 'stabil' (Floyd, 2008:2-3).

Meski mendapat tantangan dari banyak pihak, namun topik lingkungan tetap menarik perhatian tidak sedikit kalangan dalam level internasional. Munculnya isu lingkungan dalam level global ini tidak terlepas dari peran banyak pihak. Pihak-pihak inilah yang memunculkan tema degradasi lingkungan sebagai suatu ancaman bagi kehidupan manusia. Setelah mengetahui hal ini, diharapkan masyarakat internasional bisa melakukan langkah nyata untuk mengatasi problem lingkungan yang ada. Apa yang mereka lakukan ini dikenal sebagai usaha sekuritisasi lingkungan.

\section{SEKURITISASI LINGKUNGAN}

Sekuritisasi lingkungan merupakan upaya menjaga atau mempertahankan lingkungan lokal dan biosfer yang ada di Bumi. Isu lingkungan ini memunculkan aktor-aktor yang terlibat di dalamnya, yakni kelompok epistemik, gerakan sosial, pemerintah, dan organisasi-organisasi internasional. Kelompok-kelompok yang terlibat dalam sekuritisasi lingkungan mengagendakan kegiatan mereka ke dalam agenda ilmiah dan politik. Agenda ilmiah ini lebih menekankan pada kegiatan ilmu pengetahuan dan bersifat non-pemerintah. Agenda ini dibentuk di luar arena politik oleh ilmuwan dan institusi penelitian dengan menunjukkan permasalahan-permasalahan lingkungan yang dapat mengancam kelangsungan hidup peradaban saat ini. Di sisi lain, agenda politik berada di lingkungan pemerintahan. Agenda ini berisikan proses pengambilan keputusan dan kebijakan-kebijakan yang mengatur cara mengatasi masalah-masalah lingkungan. Kebijakan-kebijakan tersebut antara lain ditujukan untuk mengurangi aktifitas manusia yang menimbulkan efek samping berupa degradasi lingkungan serta meningkatkan kemampuan masyarakat untuk beradaptasi terhadap perubahan iklim (Detraz dan Betsill, 2009:308).

Setiap agenda dalam sekuritisasi lingkungan memiliki peran sendiri. Agenda ilmiah mengemukakan ancaman yang ada dalam suatu masalah lingkungan, kemudian 
memunculkan tindakan sekuritisasi maupun desekuritisasi. Sementara itu, agenda politik memunculkan perhatian publik dan mencari cara guna menghadapi isu yang dimunculkan. Meskipun saling berhubungan, kedua agenda tersebut melalui proses yang berbeda. Agenda ilmiah harus memenuhi standar akademis. Agenda politik dapat dibentuk oleh standar pemerintah, media, dan masyarakat.

Sejalan dengan hal ini telah banyak pertemuan di level internasional yang dilaksanakan untuk membahas strategi dalam menghadapi permasalahan-permasalahan terkait degradasi lingkungan. Dalam forum-forum seperti itu biasanya perwakilan dari negara-negara berkembang akan lebih mengedepankan fakta tentang bagaimana kerusakan lingkungan berdampak negatif terhadap populasi penduduk yang paling rentan yang sebagian besar memang berada di belahan Bumi selatan. Ini disebabkan karena kebanyakan dari mereka masih menggantungkan hidupnya pada sumber daya alam, seperti di bidang pertanian dan kelautan (Barnett dan Adger, 2007). Namun jika dicermati lebih lanjut, sikap para perwakilan negara-negara Dunia Ketiga ini pada dasarnya merupakan salah satu cara mereka untuk menyatakan bahwa negara-negara industri memiliki tanggung jawab yang lebih besar untuk mengontrol gas rumah kaca (Detraz dan Betsill, 2009:310).

Namun cara pandang seperti ini seolah mempersempit alternatif strategi untuk menghadapi degradasi lingkungan. Tanggung jawab negara-negara industri untuk mengontrol emisi gas rumah kaca tersebut menunjukkan bahwa keamanan lingkungan seakan hanya menekankan pada hubungan antara konsumsi energi dan perubahan iklim. Implikasi dari adanya relasi ini adalah potensi ketegangan yang menyertainya mengingat keamanan energi biasanya diasosiasikan dengan negara yang cenderung lekat dengan logika realisme dan prinsip menang-kalahnya. Di sisi lain, keamanan iklim pada umumnya dikaitkan dengan pendekatan kooperatif. Oleh sebab itu, jika keamanan lingkungan hanya ditekankan pada sektor energi, maka penyelesaian terhadap permasalahan-permasalahan terkait perubahan iklim cenderung lebih bersifat antagonis daripada kooperatif (Trombetta, 2008: 596-597).
PEMANASAN GLOBAL SEBAGAI SALAH SATU ISU SEKURITISASI LINGKUNGAN

Pada dekade terakhir, isu lingkungan mendapat perhatian luas masyarakat dalam studi keamanan. Pemicunya adalah pemanasan global. Isu ini berkembang sejalan dengan perubahan paradigma keamanan yang sebelumnya berfokus ke negara menjadi bergeser pada manusia. Pemanasan global yang mengancam kelangsungan keamanan lingkungan dan hidup manusia telah mendorong kelompok-kelompok yang terlibat dalam masalah ini-yang dalam konsep sekuritisasi lebih dikenal dengan sebutan securitizing actors-untuk mengagendakan langkah nyata. Mereka melakukan securitizing move dengan menggaungkan dampak bencana-bencana yang terjadi di luar kendali manusia (Trombetta, 2008:596). Kejadian-kejadian semacam ini memerlukan respon darurat yang pengambilan keputusannya dilakukan di luar mekanisme normal yang selama ini dijalankan.

Pemanasan global pada dasarnya merupakan fenomena peningkatan temperatur dari tahun ke tahun karena terjadinya efek rumah kaca yang disebabkan oleh meningkatnya emisi gas-gas, seperti karbondioksida, metana, dinitrooksida, dan Chloro Fluor Carbon (CFC) sehingga energi matahari terperangkap dalam atmosfer. Ancaman terhadap kelangsungan lingkungan biosfer muncul dari dampak yang ditimbulkannya. Dampak tersebut diperkirakan akan nampak pada 2100. Dampakdampak ini antara lain meningkatnya temperatur atmosfer sekitar 1,5-4,5?C; musnahnya berbagai jenis keanekaragaman hayati; meningkatnya frekuensi dan intensitas hujan badai, angin topan, dan banjir; serta mencairnya es dan gletser di kutub yang mengakibatkan kenaikan permukaan laut hingga menyebabkan banjir yang luas. Pada 2100, diperkirakan permukaan air laut naik sekitar 15-95 $\mathrm{cm}$. Jumlah tanah kering yang potensial menjadi gurun karena kekeringan yang berkepanjangan juga diprediksi akan meningkat. Kenaikan suhu air laut menyebabkan terjadinya pemutihan karang. Kerusakan terumbu karang di seluruh dunia juga diperkirakan terjadi pada waktu yang sama. Selain itu, diprediksi akan terjadi peningkatan frekuensi kebakaran hutan serta penyebaran penyakitpenyakit tropis, seperti malaria, ke daerah-daerah baru karena bertambahnya populasi serangga, terutama nyamuk. 
Untuk menghadapi ancaman pemanasan global tersebut, berbagai pihak telah mengagendakan upaya sekuritisasi. Agenda ilmiah meliputi berbagai penelitian yang dilakukan ilmuwan. Menurut penelitian yang dilakukan oleh NASA's Goddard Institute for Space Studies, terjadi kenaikan suhu rata-rata dunia sebesar 0,8?C sejak 1880 . Penelitian ini juga menyimpulkan bahwa 2 dekade terakhir abad ke-20 merupakan era terpanas selama 400 tahun ke belakang, bahkan juga bisa menjadi yang terhangat selama beberapa milenium. Lembaga bentukan PBB untuk mengatasi masalah perubahan iklim, Intergovernmental Panel on Climate Change (IPCC), melaporkan bahwa 11 tahun terakhir adalah era terpanas dibandingkan 1850. Selain itu, Arctic Climate Impact Assessment melaporkan bahwa sekitar tahun 200 hingga 2004, suhu rata-rata di Alaska, barat Kanada, dan timur Rusia meningkat dua kali melebihi rata-rata peningkatan suhu global. Hamparan es yang luas semakin banyak yang mencair dengan kecepatan yang bertambah dari hari ke hari. Bahkan, diperkirakan bahwa pada 2040 atau justru lebih cepat dari itu, di Artik akan muncul musim panas tanpa es.

Di samping berbagai kegiatan ilmiah di atas, agenda politik juga dilakukan dengan ditandatanganinya kesepakatan bersama dalam upaya mengatasi pemanasan global. Kesepakatan penting tersebut salah satunya adalah Protokol Kyoto. Protokol ini ditandatangani pada 1997 dan baru diterapkan pada 16 Februari 2005. Secara umum, protokol ini berisi ketentuan bagi negara-negara industri maju untuk menurunkan emisinya secara kolektif sebesar 5,2\% dari tingkat emisi pada 1990. Negara-negara maju diharapkan dapat membantu negara-negara berkembang untuk mengurangi tingkat emisinya. Selain itu, terdapat beberapa ketentuan yang memuat upaya-upaya untuk mengurangi emisi gas rumah kaca, yang tercakup dalam Kyoto Mechanism. Mekanisme Kyoto terdiri dari Clean Development Mechanism (CDM), Joint Implementations, dan Carbon Trading.

Kesepakatan lain yang juga tidak kalah pentingnya dalam usaha mengatasi pemanasan global adalah Vienna Convention for The Protection of The Ozone Layer. Ketentuan-ketentuan spesifik konvensi ini diatur dalam Protokol Montreal. Protokol ini berisi kewajiban untuk mengurangi penggunaan bahan-bahan kimia perusak ozon, terutama CFC.

Perjanjian-perjanjian inilah yang nantinya bisa diterjemahkan ke dalam bentuk langkah nyata oleh masyarakat luas untuk turut mengatasi dampak buruk pemanasan global. Ini dilakukan karena masyarakat merasa memiliki kewajiban moral untuk menjaga kelestarian lingkungan tempat mereka tinggal guna menjamin kelangsungan hidup. Langkah nyata yang mereka lakukan berbeda-beda tergantung pada kemampuan masing-masing.

CDM misalnya, bisa dijadikan acuan untuk mencapai pembangunan berkelanjutan, terutama melalui pengembangan energi baru terbarukan. Di beberapa negara, sudah terdapat perusahaan yang menyediakan energi dari tenaga angin dan matahari yang dapat diperbaharui. Selain itu, pembangunan berkelanjutan juga bisa dilakukan dengan reforestasi untuk menjamin ketersediaan hutan sebagai paru-paru dunia, misalnya melalui penghematan pemakaian produk-produk berbahan dasar kayu, seperti kertas.

Perjanjan lain, seperti Protokol Montreal, juga bisa diaplikasikan dengan banyak langkah oleh semua lapisan masyarakat. Perusahaan-perusahaan bisa mengaplikasikannya dengan memproduksi barang-barang berteknologi tinggi yang ramah lingkungan. Salah satunya adalah mobil hibrida yang hemat bensin sehingga bisa mengeluarkan lebih sedikit emisi. Contoh lain adalah energi solar untuk keperluan air panas rumah tangga. Perangkat elektronik ini hanya mengeluarkan sedikit sekali gas rumah kaca daripada pemanas air listrik. Tentunya usaha para produsen ini akan bermakna jika mendapat sambutan positif dari konsumen yang juga berkomitmen untuk mengatasi pemanasan global.

Selain menghemat pemakaian barang-barang berbahan kertas, masyarakat bisa turut berpartisipasi dalam mengurangi produksi karbondioksida sebagai salah satu unsur gas rumah kaca melalui hal-hal kecil lain. Beberapa contohnya adalah mengatur temperatur Air Conditioner (AC) agar tidak terlalu dingin, mematikan secara tuntas alat listrik, memastikan bahwa ban mobil tidak kurang angin, tidak memanfaatkan fitur pengering mesin cuci, menggunakan fasilitas antar-jemput yang disediakan sekolah ataupun tempat kerja, dan sebagainya.

Di samping karbondioksida, metana adalah zat yang banyak terkandung dalam gas rumah kaca. Gas ini ternyata 
dikeluarkan secara alami oleh sapi dalam setiap nafasnya. Oleh karena itu, untuk turut mengurangi produksi gas rumah kaca, maka masyarakat dapat memulai mengurangi konsumsi hewan ternak seperti sapi.

\section{KESIMPULAN}

Perkembangan fenomena pada hubungan internasional menggeser paradigma dalam memandang keamanan. Ia tak lagi dipandang dalam kerangka negara tetapi mengerucut ke level individu. Pergeseran paradigma keamanan yang awalnya berorientasi pada negara yang sempit cakupannya, kini perhatiannya telah meluas kepada manusia. Pergeseran yang berawal pada aspek ekonomi terus bergulir ke isu lingkungan. Pemanasan global sebagai salah satu pokok bahasan dalam isu lingkungan merupakan penegasan atas pergeseran paradigma studi HI.

Dampak yang ditimbulkan oleh pemanasan global mendorong aktor-aktor internasional untuk bekerja sama lintas batas negara. Tidak hanya negara, aktor-aktor nonpemerintah, terutama individu, juga terlibat dalam usaha mengatasi dampak buruk pemanasan global. Ini terjadi karena ia lebih dekat dengan problem pemanasan global yang selama ini tidak dianggap sebagai isu politik tingkat tinggi. Daya jangkau masyarakat terhadap masalah ini lebih dekat jika dibandingkan dengan isu politik tingkat tinggi, khususnya militer. Sebaliknya, negara akan lebih dekat dengan isu keamanan militer dibandingkan masyarakat pada level individu. Isu pemanasan global semakin menjadi ancaman kehidupan manusia karena berdampak langsung terhadap lingkungan sebagai ruang hidup. Oleh karena itu individu memiliki tanggung jawab moral lebih besar untuk mengatasi permasalahan ini, jika dibandingkan dengan masalah politik tingkat tinggi. Persepsi masyarakat akan pemanasan global yang berdampak buruk pada segala aspek kehidupan dan mengancam peradabannya semakin menegaskan bahwa keamanan manusia tak lagi dipahami dalam konteks batas negara.

Perspektif keamanan manusia ini membuat studi HI dapat menjelaskan persoalan dalam dinamika kehidupan individu dan masyarakat yang juga menjadi aktor dalam bidang ini. Persoalan yang terus berkembang seiring perkembangan zaman menuntut studi HI tak lagi hanya berpusat pada negara. Pergeseran perspektif ini dapat mendekatkan akademisi ilmu HI pada obyek yang dipelajarinya, tidak seperti sebelumnya ketika studi tersebut fokus pada negara sehingga membuat akademisi mempelajari objek di luar dirinya.

\section{REFERENSI}

Bajpai, Kanti. 2003. The Idea of Human Security. International Studies 40.

Barnett, Jon dan Adger, W.N. 2007. Climate Change, Human Security and Violent Conflict. Political Geography, 26.

Buzan, Barry, et.al. 1998. Security A New Framework for Analysis. London: Lynne Rienner Publisher.

Carr, E. H. 1939. The Twenty Years' Crisis: 1919 - 1939. Palgrave Macmillan UK.

De Wilde, Jaap. 2008. Environmental Security Deconstructed, dalam Hans G. Brauch (ed.). Globalization and Environmental Challenges: Reconceptualizing Security in The 21st Century. Berlin: Springer.

Detraz, Nicole dan Betsill, M.M. 2009. Climate Change and Environmental Security: For Whom the Discourse Shifts. International Studies Perspectives, 10.

Floyd, Rita. 2008. The Environmental Security Debate and its Significance for Climate Change. (Daring), (http:// wrap.warwick.ac.uk/1083/1/ WRAP_Floyd_Floyd_The_Environmental_Security_Debate_WRAP.pdf, diakses 14 September 2017).

Held, David dan McGrew A. (eds.). 2003. The Global Transformations Reader An Introduction to the Globalization Debate. Cambridge: Polity Press.

Kegley, C.W. and Wittkopf, E.R. (eds.). 2001. World Politic: Trend and Transformation 8th. Boston: Bedford/St. Martins.

Martinovsky, Petr. 2011. Environmental Security and Clasical Typology of Security Studies, The Science for Population Protection, 2. (Daring), (http://www.population-protection.eu/ attachments/039_vol3n2_martinovsky_eng.pdf., diakses 16 Agustus 2017).

Thomas, N. and Tow, W.T. 2002. The Utility of Human Security: Sovereignty and Humanitarian Intervention, Security Dialogue, 33.

Trombetta, M.J. 2008. Environmental Security and Climate Change: Analysing The Discourse, Cambridge Review of International Affairs, 21:4. (Daring), (http://dx.doi.org/10.1080/ 09557570802452920, diakses 5 September 2017).

Worku, Mogues. 2007. The Missing Links: Poverty, Population, and the Environment in Ethiopia. Dalam Environmental Change and Security Program (ed.) Focus on Population, Environment, and Security. Washington, DC: Woodrow Wilson International Center for Scholars. 